\title{
The Settlement of Joint Property in Religious Courts of Indonesia (A Case in the Religious Court of South Jakarta)
}

\author{
Isnawati Rais
}

\begin{abstract}
The Settlement of Joint Property in Religious Courts of Indonesia (A Case in the Religious Court of South Jakarta). The settlement of joint property, after husbands and wives divorced, is a crucial issue in the Religious Courts of Indonesia. According to the provisions of the Islamic Law Compilation (KHI) and Marriage Law No. 1/1974, a joint property should be divided equally if done peacefully. This research analyzes the joint property settlement after divorce in the Religious Court of South Jakarta and compares it with a number of cases in other similar institutions. This study finds out that the rules as stipulated both in the KHI and Marriage Law No. 1/1974, was not rigidly applied by the judges. Instead, the judges at the Religious Court of South Jakarta took a flexible and casuistic solution for the disputes over the sharing of joint property between divorced couples. The settlement methods used by the judges vary, depending on the case that occurs empirically. The peaceful settlement was also pursued by the Religious Court of South Jakarta, although in general, it was unsuccessful.
\end{abstract}

Keywords: joint property settlement, religious court, Islamic law compilation

\begin{abstract}
Abstrak: Penyelesaian Harta Bersama di Pengadilan Agama Indonesia (Kasus di Pengadilan Agama Jakarta Selatan). Pembagian harta bersama setelah suami-isteri bercerai menjadi isu krusial di lingkungan Peradilan Agama. Menurut ketentuan Kompilasi Hukum Islam dan Undang-undang Nomor 1 Tahun 1974 tentang Perkawinan harta bersama dibagi sama rata jika dilakukan secara damai. Studi ini menganalisis implementasi pembagian harta bersama pasca perceraian di Pengadilan Agama Jakarta Selatan dengan mengkomparasikan sejumlah kasus gugatan pembagian harta bersama. Studi ini menemukan bahwa aturan bagi dua (sama rata), sebagaimana yang ditetapkan dalam KHI dan Undang-undang Nomor 1 Tahun 1974 tentang Perkawinan, tidak diterapkan secara kaku oleh para hakim. Pada kenyataannya, Para hakim di Pengadilan Agama Jakarta Selatan justeru menempuh jalan fleksibel dan kasuistik dalam sengketa pembagian harta bersama antara suami dan isteri pasca perceraian. Pilihan jalan yang digunakan oleh para hakim ini sangat tergantung pada kasus-kasus yang terjadi secara empirik. Upaya perdamaian juga ditempuh oleh Pengadilan Agama Jakarta Selatan, walaupun pada umumnya tidak berhasil.
\end{abstract}

Kata Kunci: harta bersama, Pengadilan Agama, Kompilasi Hukum Islam 


\section{Introduction}

The term joint property is generally known in societies whose customs recognize the existence of a mixture of wealth. In Indonesian legislation, the issue of joint assets is regulated in Presidential Instruction R.I No. 1 of 1991 concerning the Compilation of Islamic Law in Indonesia and Marriage Law No. 1 of 1974 concerning Marriage. In the two regulations, it is determined that if the marriage breaks up, either because of death or divorce, then the joint property is divided in two, as long as it is not specified otherwise in the marriage agreement.

In addition to the provisions as stipulated in law number 1 of 1974 concerning marriage, in Indonesia also applies Compilation of Islamic Law relating to the sharing of shared assets as stipulated in Article 96 and 97 Compilation of Islamic Law which also regulates the same thing that the distribution of shared property is well death or divorce, each gets half of the joint property. ${ }^{1}$

While according to the law of the civil law considers that when husbands and wives at the time of going to marry do not have a property separation agreement between them then the consequence of the marriage is the mixing of the husband's wealth and wife into one property of both together and their respective sections each in this wealth is half. In custom law embracing the central system between the Islamic Law system and the Civil Law Code it is possible that some of the wealth

${ }^{1}$ Muhammad Agus Rudianto, "Pelaksanaan Pembagian Harta Bersama (Gono Gini) dalam Praktik di Pengadilan Agama Kelas I A Samarinda.” Jurnal Beraja Niti 2, No. 9, (2013): h. 2. Liky Faizal. "Harta bersama dalam Perkawinan." Ijtimaiyya: Jurnal Pengembangan Masyarakat Islam 8, no. 2 (2015): p. 77-102. Felicitas Marcelina Waha. "Penyelesaian Sengketa atas Harta Perkawinan Setelah Bercerai." Lex et Societatis 1, no. 1 (2013). Arifah S. Maspeke, dan Akhmad Khisni. "Kedudukan Harta Bersama dalam Perkawinan Menurut Fiqih dan Hukum Positif Indonesia Serta Praktik Putusan Pengadilan Agama." Jurnal Hukum Khaira Ummah 12, no. 2 (2017): p. 173-184. Mochammad Soleh Alaidrus. "Pelaksanaan Pembagian Harta Perkawinan dalam Perkawinan Poligami (Studi di Pengadilan Agama Bekasi)." Notarius 1, no. 1 (2011): p. 1-18. Ahmad Ibrahim. "Penerapan Asas Ius Contra Legem dalam Pembagian Harta Bersama di Pengadilan Agama Mojokerto: Studi Putusan No: 0521/Pdt. G/2013/PA.” PhD diss., Universitas Islam Negeri Maulana Malik Ibrahim, 2016. Zulfiqar Mokodompit. "Penerapan Hukum Positif Terhadap Harta Gono-Gini Dihubungkan dengan Hukum Islam.” Lex Administratum 3, no. 6 (2015). Yunthia Misliranti. "Kedudukan dan Bagian Isteri Atas Harta Bersama Bagi Isteri yang Dicerai dari Pernikahan Sirri." PhD diss., Program Pasca Sarjana Universitas Diponegoro, 2006. 
is mixed into property with the husband and wife. ${ }^{2}$

The problem that arises is whether the provisions for these two equals portions will fulfill a sense of justice. This requires serious consideration. If both parties (husband and wife) work together, the distribution of shared assets for two equals seems to be easily accepted by the parties. Similarly, if the husband works while the wife only takes care of the household, then such a distribution model will not cause problems. Apart from Islam recognizes the concept of division of labor between husbands and wives in the public and domestic sectors, Islam also teaches that husbands have an obligation to earn a living to finance their children and wives. Judging from this perspective, the model of the distribution of shared assets for two equally seems to be also not too difficult for parties to accept.

But what if the wife works while her husband does not, will they also apply a settlement model for two equally? This requires careful consideration. It seems unfair if the wife who has struggled to collect property and carry the burden that is not essentially her obligation to help alleviate her husband's burden, then, because of divorce, the results of her labor must be shared with her husband equally. The question now is how fair is the verdict? If the decision is deemed unfair, are the judges allowed to override the statutory provisions and take other ways to fulfill a sense of justice?

Another problem that also often arises in the case of joint assets is the difficulty to prove that someone has a large share of the disputed property. Even though Law No. 1 Th 1974 article 35 paragraph (1), and

${ }^{2}$ Hilda Yuwafi Nikmah dan Pranoto, "Pembagian Harta Besama Akibat Perceraian dari Perkawinan Campuran Berdasarkan Undang-Undang Nomor 1 Tahun 1974 tentang Perkawinan dan Kaidah Hukum Perdata Internasional", Pirvate Law: Jurnal Pemikiran dan Penelitian Hukum, No. 6, (2014): p. 77. Zulfa Aminatuz Zahro. "Analisis Yuridis Terhadap Dasar Pertimbangan Hakim dalam Menetapkan Harta Bersama Tanpa Adanya Perceraian di Pengadilan Agama Malang: Studi Kasus Perkara Nomor: 2198/Pdt. G/2012." PhD diss., UIN Sunan Ampel Surabaya, 2014. Winda Wijayanti. "Kedudukan Istri dalam Pembagian Harta Bersama Akibat Putusnya Perkawinan Karena Perceraian Terkait Kerahasiaan Bank.” Jurnal Konstitusi 10, no. 4 (2013): h. 709-730. Andayanti Lubis. "Kajian Yuridis Pertanggungjawaban Atas Harta Bawaan Isteri Terhadap Hutang Suami dengan Jaminan Harta Bersama (Studi Kasus Putusan Nomor: 295/ Pdt. G/2001/PN. Mdn).” PhD diss., Program Pascasarjana Universitas Diponegoro, 2009. 
(2) have provided clear and explicit explanations of shared assets-that is, assets acquired during marriage are exempted from assets acquired from inheritance and gifts - but because generally the disputed assets are in control one of the parties or has been in his name, it is very possible for those who control the property will say that this is not a joint asset, but a gift or inheritance. If this happens, the judge will find it difficult to prove whether the claim submitted by either party is true or not,

\section{Institutionalization of Joint Assets}

In Islamic law, both in the Qur'an and as-Sunnah, there are no provisions governing the distribution of shared assets. Due to the absence of provisions governing the issue that sharing property together became an ijtihadiyah problem whose settlement was left to the government/judge.

According to Ismail Muhammad Syah, the authors of the books of figh of the past had not discussed the problem of shared assets in the book is because in general, they are Arabs who do not recognize the customs of property collections (syirkah/musyarakah) in the household. ${ }^{3}$ Therefore, the institutionalization of joint assets in a household is generally based on the urf or customs of a country that does not separate the property rights of husband and wife. In other words, common assets generally appear in a community environment that emphasizes a sense of togetherness in household affairs and consider marriage contracts to contain the agreement of partners in fostering domestic life. Therefore, all assets acquired after the marriage contract are considered joint assets between husband and wife, without questioning who is more likely to obtain the property.

Joint assets in marriage are classified in the form of syirkah abdan mufawwadhah, because in general husband and wife in Indonesian society both work to earn a living for their daily family. The Sheikh of Al-Banjari of Banjarmasin called the joint property as the "treasure property" or a forbidden by a taboo property. However, now the problems relating

${ }^{3}$ Ismuha, Pencaharian Bersama Suami Istri Ditinjau dari Sudut Undang-undang Perkawinan Tahun 1974 dan Hukum Islam, (Jakarta: Bulan Bintang, 1986), Cet. 1, p. 282. 
to joint assets in marriage are even more widespread, which shows that the Indonesian Muslim community is in dire need of legal certainty in terms of handling the case.

One example of a joint property case that was once decided by a judge using customary law was the decision of the 1928 Kutoarjo Religious Court. The court first divided the property of Gono-gini before determining the tirkah (heritage) of a dead husband. The distribution of the gono-gini is done by calculating one versus one which is different from the principle of "sepikul segendong" in customary law. Such a method was applied in the District Court (Landraad) after the matter of inheritance and joint assets were under the authority of the District Court. ${ }^{4}$

Therefore, in establishing the framework of Islamic Law Compilation (KHI), Indonesian scholars seek to include all related problems in KHI by taking shirkah as a basis for formulating legal principles. To deal with the issue of joint property, the committee of compilation approaches the drafting process by combining shirkah abdan and customary law. ${ }^{5}$

In the Compilation of Islamic Law, the provisions for the stipulation of joint assets are regulated in chapter XIII concerning Assets in Marriage, starting from article 85 to article 97 . The provisions state that the joint assets are separated from their respective personal assets where personal property remains privately owned and fully controlled by the owner (husband or wife). In addition, the joint assets become the joint rights of the spouses and are completely separated from personal property.

Joint assets take place from the date of marriage without questioning

${ }^{4}$ Busthanul Arifin, Pelembagaan Hukum Islam di Indonesia: Akar Sejarah, Hambatan, dan Prospeknya (Jakarta: Gema Insani Press, 1996), p. 122. Sumadi Matrais. "Kemandirian Peradilan Agama dalam Perspektif Undang-Undang Peradilan Agama." Jurnal Hukum Ius Quia Iustum 15, no. 1 (2008). R Ahmad. "Peradilan Agama di Indonesia." YUDISIA: Jurnal Pemikiran Hukum dan Hukum Islam 6, no. 2 (2015): p. 311-339. Nashori Ghofur Abdul. "Peradilan Agama di Indonesia Pasca UU No. 3 Tahun 2006, Sejarah, Kedudukan \& Kewenangan.” (Yogyakarta: UII Pers, 2007).

${ }^{5}$ M. Yahya Harahap, Kedudukan Kewenangan dan Acara Peradilan Agama (Undangundang No. 7 Tahun 1989) (Jakarta: Pustaka Kartini, 1997), Cet. 3, h. 297. Moh, Syarifah Marwiyah Sutomo, dan Nur Mawaddah Warohmah. "Akar Historis Pengadilan Agama Masa Orde Baru." Yudisia: Jurnal Pemikiran Hukum dan Hukum Islam 7, no. 2 (2016): p. 267-284. 
who earn and on behalf of whom is registered. In addition, it is also stipulated that without mutual agreement, the husband or wife may not alienate or move the property. Debts for family purposes are borne by the joint assets. Whereas, in serial marriage or polygamy, the form of shared assets is separated between husband and each wife. If the marriage is broken (dead or divorced), then the joint property is divided into two, each gets a half part, and if a death occurs, the part becomes tirkah (heritage). ${ }^{6}$

According to the State Law number 1 of 1974 article 37 regarding marriage, if a marriage breaks up because of divorce, the joint property is waived according to their respective laws. In the explanation of article 37 , the stated laws may be based on religious law, customary law or other laws. The articles of 96 and 97 of the Compilation of Islamic Laws also stress that the proportion of shirkah for both death divorce and life divorce should be equal regardless the number of the joint property remains unknown.

\section{Joint Property Lawsuits in the South Jakarta Religious Court}

Dividing joint or collective property in a marriage is not always easy. It can be seen from numerous lawsuit cases related to this problem. In the South of Jakarta Religious Court. for instance, the divorce lawsuit and joint property cases at the same time might occur as well as the plaintiff and defendant may only demand joint property since they are already divorced. Therefore, they prepare a separate lawsuit. The following table illustrates the number of joint property lawsuit at Jakarta Selatan Religious Court, as happened from 2005 to $2010 .^{7}$

${ }^{6}$ Cik Hasan Bisri, Kompilasi Hukum Islam dan Peradilan Agama dalam Sistem Hukum Nasional, (Jakarta: Logos Wacana Ilmu, 1999), Cet. 2, p. 62-63.

${ }^{7}$ Archives of the Religious Court of South Jakarta. 
Table 1

The List of Joint Property Lawsuits in the South Jakarta Religious Court 2005-2010

\begin{tabular}{|c|c|c|c|}
\hline No. & Case number & Decision Date & Information \\
\hline 1 & 45/Pdt.G/2005/PA.JS & May 9, 2005 & \\
\hline 2 & 96/Pdt.G/2006/PA.JS & May 29, 2006 & \\
\hline 3 & 185/Pdt.G/2006/PA.JS & August 28, 2006 & \\
\hline 4 & 176/Pdt.G/2007/PA.JS & July 4, 2007 & \\
\hline 5 & 1313/Pdt.G/2007/PA.JS & January 30,2008 & \\
\hline 6 & 1650/Pdt.G/2007/PA.JS & July 14, 2007 & $\mathrm{NO}$ \\
\hline 7 & 498/Pdt.G/2008/PA.JS & October 21, 2008 & Withdrawn \\
\hline 8 & 872/Pdt.G/2008/PA.JS & April 6, 2009 & \\
\hline 9 & 967/Pdt.G/2008/PA.JS & February 16, 2009 & $\mathrm{NO}$ \\
\hline 10 & 1771/Pdt.G/2008/PA.JS & 15 April 2009 & \\
\hline 11 & 0662/Pdt.G/2009/PA.JS & October 27, 2009 & \\
\hline 12 & 891/Pdt.G/2009/PA.JS & January 26, 2010 & \\
\hline 13 & 0914/Pdt.G/2009/PA.JS & July 8, 2010 & $\mathrm{NO}$ \\
\hline 14 & 1147/Pdt.G/2009/PA.JS & October 20, 2009 & Withdrawn \\
\hline 15 & 1187/Pdt.G/2009/PA.JS & August 18th, 2009 & \\
\hline 16 & 1271/Pdt.G/2009/PA.JS & August 12th, 2009 & \\
\hline 17 & 1414/Pdt.G/2009/PA.JS & January 6,2010 & \\
\hline 18 & 1978/Pdt.G/2009/PA.JS & July 26, 2010 & \\
\hline 19 & 2011/Pdt.G/2009/PA.JS & January 21, 2010 & \\
\hline 20 & 2101/Pdt.G/2009/PA.JS & February 11, 2010 & $\mathrm{NO}$ \\
\hline 21 & 2432/Pdt.G/2009/PA.JS & February 18,2010 & \\
\hline 22 & 0503/Pdt.G/2010/PA.JS & May 11, 2010 & \\
\hline 23 & 0608/Pdt.G/2010/PA.JS & May 5, 2010 & Withdrawn \\
\hline 24 & 0618/Pdt.G/2010/PA.JS & December 14,2010 & \\
\hline 25 & 0705/Pdt.G/2010/PA.JS & March 10, 2011 & \\
\hline 26 & 0899/Pdt.G/2010/PA.JS & July 21, 2010 & \\
\hline 27 & 0937/Pdt.G/2010/PA.JS & June 15,2010 & \\
\hline 28 & 0972/Pdt.G/2010/PA.JS & July 13 th, 2010 & \\
\hline 29 & 1297/Pdt.G/2010/PA.JS & July 5, 2010 & \\
\hline 30 & 1318/Pdt.G/2010/PA.JS & August 31, 2010 & \\
\hline 31 & 1375/Pdt.G/2010/PA.JS & July 26, 2010 & \\
\hline
\end{tabular}




\begin{tabular}{llll}
\hline 32 & 1825/Pdt.G/2010/PA.JS & October 12, 2010 & \\
\hline 33 & 2440/Pdt.G/2010/PA.JS & March 30, 2011 & NO \\
\hline 34 & 2530/Pdt.G/2010/PA.JS & 11 April 2011 & \\
\hline
\end{tabular}

The above table indicates that of 34 cases in total, 3 cases were withdrawn, 5 cases were rejected $(\mathrm{NO}=$ Niet Ovankelijk verklaard $)$ and the rest 26 cases had been settled and were legally binding.

The following table depicts the development of the number of lawsuits on joint property in the Religious Court of South Jakarta each year.

Table 2

The Total Lawsuit Cases of Joint Lawsuit Every Year from 2005 to $2010^{8}$

\begin{tabular}{cccccc}
\hline No. & Year & Number of Cases & Withdrawn & NO & Solved \\
\hline 1 & 2005 & 1 & - & - & 1 \\
\hline 2 & 2006 & 2 & - & - & 2 \\
\hline 3 & 2007 & 3 & - & 1 & 2 \\
\hline 4 & 2008 & 4 & 1 & 1 & 2 \\
\hline 5 & 2009 & 11 & 1 & 2 & 8 \\
\hline 6 & 2010 & 13 & 1 & 1 & 11 \\
\hline \multicolumn{2}{c}{ Total } & 34 & 3 & 5 & 26 \\
\hline
\end{tabular}

The above table indicates the increase of lawsuit cases number on joint property in Religious Court of South Jakarta within 2005-2010. As the table shows, in 2005 there was only one joint property case and it was settled as well. In 2006, the number of lawsuits joint property was 2 cases, which all also had been settled. In the following years, in 2007, the number of lawsuits joint property increased as many as three cases, consisting of one NO case and two settled cases. In 2008, the number of joint property case grew to four cases which consist of one withdrawn case, one NO case, and two settled cases. Furthermore, in 2009, the number of lawsuits joint property increased sharply, as many as 11 cases,

\footnotetext{
${ }^{8}$ Archives of the Religious Court of South Jakarta.
} 
consisting of one withdrawn case, two NO cases, and eight settled cases. Whereas in 2010, the number of joint property claim increased as many as 13 cases, consisting of one withdrawn case and one $\mathrm{NO}$ case.

This study will not examine the withdrawn cases either because of retraction or NO. The reason is that both types of lawsuit cases are clearly are not in the process of trial. The researcher, then, will only analyze 26 cases, which are identified as the settled cases.

Table 3

The Lawsuit Verdict of Joint Property At Religious Court of South Jakarta9

\begin{tabular}{|c|c|c|c|c|}
\hline No. & Case number & Decision Date & Information & Verdict \\
\hline 1 & 45/Pdt.G/2005/PA.JS & $09-05-2005$ & $\begin{array}{l}\text { An employed wife sued an } \\
\text { employed husband }\end{array}$ & $\begin{array}{l}\text { Equally } \\
\text { divided }\end{array}$ \\
\hline 2 & 96/Pdt.G/m2006/PA.JS & $29-05-2006$ & $\begin{array}{l}\text { An unemployed wife sued } \\
\text { her employed husband }\end{array}$ & Settled \\
\hline 3 & 185/Pdt.G/2006/PA.JS & $28-08-2006$ & $\begin{array}{l}\text { An unemployed wife sued } \\
\text { her employed husband }\end{array}$ & $\begin{array}{l}\text { Equally } \\
\text { divided }\end{array}$ \\
\hline 4 & 176/Pdt.G/2007/PA.JS & 04-07-2007 & $\begin{array}{l}\text { An employed husband sued } \\
\text { an employed wife }\end{array}$ & $\begin{array}{l}\text { Equally } \\
\text { divided }\end{array}$ \\
\hline 5 & 1313/Pdt.G/2007/PA.JS & $30-01-2008$ & $\begin{array}{l}\text { An unemployed wife sued } \\
\text { her employed husband }\end{array}$ & Settled \\
\hline 6 & 872/Pdt.G/2008/PA.JS & 06-04-2009 & $\begin{array}{l}\text { An employed wife sued an } \\
\text { unemployed husband }\end{array}$ & $\begin{array}{l}\text { Equally } \\
\text { divided }\end{array}$ \\
\hline 7 & 1771/Pdt.G/2008/PA.JS & $15-04-2009$ & $\begin{array}{l}\text { An employed husband sued } \\
\text { an employed wife }\end{array}$ & $\begin{array}{l}\text { Equally } \\
\text { divided }\end{array}$ \\
\hline 8 & 0662/Pdt.G/2009/PA.JS & $27-10-2009$ & $\begin{array}{l}\text { An employed husband sued } \\
\text { an employed wife }\end{array}$ & Settled \\
\hline 9 & 891/Pdt.G/2009/PA.JS & $26-01-2010$ & $\begin{array}{l}\text { An employed husband sued } \\
\text { an employed wife }\end{array}$ & $\begin{array}{l}\text { Equally } \\
\text { divided }\end{array}$ \\
\hline 10 & 1187/Pdt.G/2009/PA.JS & $18-08-2009$ & $\begin{array}{l}\text { An unemployed wife sued } \\
\text { her employed husband }\end{array}$ & $\begin{array}{l}\text { Equally } \\
\text { divided }\end{array}$ \\
\hline 11 & 1271/Pdt.G/2009/PA.JS & $12-08-2009$ & $\begin{array}{l}\text { An employed wife sued an } \\
\text { employed husband }\end{array}$ & Settled \\
\hline 12 & 1414/Pdt.G/2009/PA.JS & 06-01-2010 & $\begin{array}{l}\text { An unemployed wife sued } \\
\text { her employed husband }\end{array}$ & $\begin{array}{l}\text { Equally } \\
\text { divided }\end{array}$ \\
\hline 13 & 1978/Pdt.G/2009/PA.JS & $26-07-2010$ & $\begin{array}{l}\text { An employed wife sued an } \\
\text { employed husband }\end{array}$ & $\begin{array}{l}\text { Equally } \\
\text { divided }\end{array}$ \\
\hline
\end{tabular}

${ }^{9}$ Archives of the Religious Court of South Jakarta. 


\begin{tabular}{|c|c|c|c|c|}
\hline 14 & 2011/Pdt.G/2009/PA.JS & 21-01-2010 & $\begin{array}{l}\text { An employed wife sued an } \\
\text { employed husband }\end{array}$ & $\begin{array}{l}\text { Equally } \\
\text { divided }\end{array}$ \\
\hline 15 & 2432/Pdt.G/2009/PA.JS & $18-02-2010$ & $\begin{array}{l}\text { An unemployed wife sued } \\
\text { her employed husband }\end{array}$ & $\begin{array}{l}\text { Equally } \\
\text { divided }\end{array}$ \\
\hline 16 & 0503/Pdt.G/2010/PA.JS & $11-05-2010$ & $\begin{array}{l}\text { An employed wife sued an } \\
\text { employed husband }\end{array}$ & $\begin{array}{l}\text { Equally } \\
\text { divided }\end{array}$ \\
\hline 17 & 0618/Pdt.G/2010/PA.JS & $14-12-2010$ & $\begin{array}{l}\text { An unemployed wife sued } \\
\text { her employed husband }\end{array}$ & $\begin{array}{l}\text { Equally } \\
\text { divided }\end{array}$ \\
\hline 18 & 0705/Pdt.G/2010/PA.JS & $10-03-2011$ & $\begin{array}{l}\text { An employed wife sued an } \\
\text { employed husband }\end{array}$ & $\begin{array}{l}\text { Equally } \\
\text { divided }\end{array}$ \\
\hline 19 & 0899/Pdt.G/2010/PA.JS & $21-07-2010$ & $\begin{array}{l}\text { An employed husband sued } \\
\text { his unemployed wife }\end{array}$ & $\begin{array}{l}\text { Equally } \\
\text { divided }\end{array}$ \\
\hline 20 & 0937/Pdt.G/2010/PA.JS & $15-06-2010$ & $\begin{array}{l}\text { An employed wife sued an } \\
\text { employed husband }\end{array}$ & $\begin{array}{l}\text { Equally } \\
\text { divided }\end{array}$ \\
\hline 21 & 0972/Pdt.G/2010/PA.JS & $13-07-2010$ & $\begin{array}{l}\text { An employed wife sued an } \\
\text { employed husband }\end{array}$ & $\begin{array}{l}\text { Equally } \\
\text { divided }\end{array}$ \\
\hline 22 & 1297/Pdt.G/2010/PA.JS & $05-07-2010$ & $\begin{array}{l}\text { An employed wife sued an } \\
\text { employed husband }\end{array}$ & Settled \\
\hline 23 & 1318/Pdt.G/2010/PA.JS & $31-08-2010$ & $\begin{array}{l}\text { An unemployed wife sued } \\
\text { her employed husband }\end{array}$ & Settled \\
\hline 24 & 1375/Pdt.G/2010/PA.JS & $26-07-2010$ & $\begin{array}{l}\text { An employed wife sued an } \\
\text { employed husband }\end{array}$ & $\begin{array}{l}\text { Equally } \\
\text { divided }\end{array}$ \\
\hline 25 & 1825/Pdt.G/2010/PA.JS & $12-10-2010$ & $\begin{array}{l}\text { An employed wife sued an } \\
\text { employed husband }\end{array}$ & Settled \\
\hline 26 & 2530/Pdt.G/2010/PA.JS & $11-04-2011$ & $\begin{array}{l}\text { An employed wife sued an } \\
\text { employed husband }\end{array}$ & $\begin{array}{l}\text { Equally } \\
\text { divided }\end{array}$ \\
\hline
\end{tabular}

The above table shows that the joint property lawsuit cases submitted to the South Jakarta Religious Court are varied. The plaintiff side is not always coming from the wives, but also from the husbands. It also applies to those who work and not during their marriage. The table also indicates that the decision tended to be shared equally for both parties (the plaintiff and the defendant) where the husband obtained a half of the joint property, as the ex-wife did. However, not all joint property lawsuit case in Religious Court of South Jakarta could be settled by dividing the property equally, as stated on KHI article 97, but it can be solved by the agreement of both parties where they agree to settle the problems through other ways. 


\section{Juridical Procedure}

In accordance with the provisions of the procedural law, judges always strive to mediate the parties, so as to allow them to achieve a solution peacefully. However, if this step is unsuccessful, the trial will continue with the process of examination and decision. ${ }^{10}$

A decision regarding the division of joint property can be classified based on "who sued and who work producing joint property during the marriage." In the court, the determination of the number of property requires evidence of the plaintiff, such as notarial sale and purchase agreement, certificate and other written evidence. The judge then will examine the evidence of this written evidence to decide whether the property can be identified as joint or collective property and how they obtain the assets. After that, the judge will listen to the answers of the defendant against the plaintiff.

When the property is recognized by the defendant, without any objection at all, the judge will determine that all the treasures sued by the plaintiff as joint property, which is then set unshared. During the process in the court, the evidence to prove how the assets are obtained and when that happened is a very crucial thing because, according to KHI, joint property is those that wife and husband afford together during their marriage.

However, when the claim is rejected by the defendant and they both claim that the property is theirs, the case might turn very difficult. Both sides need to provide evidence to support their claims such as written evidence, witness, or other additional evidence. Once the verification process is considered sufficient, the judge will determine whether to grant the claim in whole or in part and reject most of the others or even may also entirely refuse it.

Another tricky issue that may occur in the determination of joint property is dishonesty of the parties. Such could be in the form of transferring property above named of someone, move the contents of savings to other accounts, or other devious means. In this case, a determination will be even more difficult to decide.

${ }^{10}$ Interview with a clerck of court on June 28 and July 42011 at the Religious Court of South Jakarta. 
However, in accordance with the provisions of procedural law, the judge will ask the plaintiff to prove his claim and ask for the evidence for the defendant's objection. The evidence could be written evidence or witnesses. Then the judge will give a determination as to believe the evidence submitted. The determination could be in favor of the defendant, by setting all the sued treasures to be joint property, or it could also be granted in part, especially if the defendant can prove that there are other treasures on behalf of or under the control of the claimant which were not included in the lawsuit. In determining the common property, the judge is greatly restricted by formal juridical procedural law, namely proof of claim and denial. When this has been done, the judge can not do other than to issue a decision, regardless perhaps there are dishonesty parties.

\section{An Overview of Case Examinations}

\section{Employed wife sued her employed husband ${ }^{11}$}

This case was registered in the case No. 45/Pdt.G/2005/PAJS and was settled on 09 May 2005. The plaintiff was Hugeshla Dewi Binti Urges Made Dewa Made Sumartah, 33 years old and a private employee, who lives in Jl. Kemang Utara 31 Rt. 001/03, Bangka village in Mampang Prapatan sub-district, South Jakarta. The defendant is Hestiafin Tachtiar Achmad Arifin bin Ir. Nur Arifin, 34 years old and a private employee, who lives in the same house on Jl. Kemang Utara 31 Rt. 001/03, Bangka village, Mampang Prapatan sub-district, South Jakarta. Both the Plaintiff and the defendant are husband and wife who married on June 17, 2001, in the official KUA of Cipayung subdistrict in East Jakarta. The plaintiff and the defendant did not have any children.

During the marriage, the plaintiff and the defendant have had a joint property, in the form of a piece of land and building on it, which is located in Pangkalan Jati village, Limo district, South Jakarta, Certificate Properties No. 02 049/Pangkalan Jati, written on behalf of the Plaintiff. The defendant admits that the land is on behalf of the Plaintiff. However, regardless the defendant recognition, as the location

${ }^{11}$ Archives of the Religious Court of South Jakarta. 
of the land and the building in a suit is not accurate, the action becomes blurred, and therefore a lawsuit against the property should be declared unacceptable (NO).

In addition, the plaintiff and the defendant also had a piece of land and building on it, located on Jl. Kemang Utara No. 31, South Jakarta, written on behalf of the Defendant. As this was still in installments and already paid/repaid Rp. 500.000.000, -, while the rest of the installments of Rp. 1,400,000,000, - (one billion four hundred million), the remaining mortgage debt was considered to be paid by both parties; plaintiff and defendant.

Furthermore, the plaintiff and the defendant also owned a Honda Stream No. Pol IIN 8175, 2002, on behalf of the Defendant, a Nissan X-Trail No. Pol 8816OP, 2004, on behalf of the Defendant. The parties also owned money amounting to approximately Rp. 100.000.000, - (one hundred million), in an account No. 301.14972.22 of Bank Muamalat Artha Loka Head Office and in the savings account No. 126-00-020-59615 of Branch Kemang Raya, South Jakarta, amounting to approximately Rp. 65.840, - (sixty-five thousand eight hundred and forty rupiahs), on behalf of both the Plaintiff and the Defendant. In addition, there was also money amounting to approximately USD. 4289, - (four thousand two hundred and eighty-nine US dollars), in account No. 8-004193016is at the City savings Bank, Jakarta, on behalf of the Defendant; money amounting to approximately Rp. 40 510. 884, - (forty million five hundred and ten thousand eight hundred and eighty-four rupiah), in savings, account No. 4361038741 of the Bank Central Asia, Branch Tebet Barat, South Jakarta, on behalf of Defendant. However, there was a refutation of the Defendant. According to the Defendant, the money had been used for the collective purposes, namely: (1) for Sequislife insurance payments on behalf of Plaintiff Rp. 8.388 million, -, through the transfer of ATM BCA dated December 26, 2004; (2) for insurance payments on behalf of the Defendant Rp. 7.583 million, - through transfer ATM BCA dated December 26, 2004; (3) for Citi Bank credit card payments on behalf of the Defendant Rp. 15.655 million, - through transfer ATM BCA dated December 26, 2004; (4) for Citi Bank credit card payments on behalf of the Defendant amounted Rp. 12.415 million, 
In the above case, the judge decided that the Plaintiffs and Defendants each entitled to $1 / 2$ of the above-mentioned joint property. A similar verdict was made by the Religious Court Judge in Balik Papan in the Case No. 496/Pdt.G/2013/PA.Bpp which was settled on January 14, 2014. The judge, in their decision, determined that Plaintiffs and Defendants each entitled to a half of joint property.

\section{Unemployed wife sued her employed husband ${ }^{12}$}

This case was registered in the case No. 0899/Pdt.G/2010/PAJS which was settled on July 21, 2010. The plaintiff was Dr. Vira Ward Istiantoro, Spm, son of Dr. Istiantoro, 38-year-old and a doctor, who lives in Jalan Bangka II \# 28 Rt. 019/02, Pela Mampang Mampang, South Jakarta Sub-district. The Defendant was Rumman binti Muhammad Faizal H, 24 years old housewife, who lives in Jalan Bintaro Permai II Rt. 005/01 No. 22, Bed \& Breakfast village in Bintaro, South Jakarta. Plaintiff and Defendant are husband and wife who married on May 8, 2004, at KUA District of Kebayoran Baru, South Jakarta, with a marriage certificate No. 391/25/V/2004. In the case, both the Plaintiff and the Defendant agreed to diminish the division of joint property. However, at the discretion of the Plaintiff, the Plaintiff was willing to submit one (1) unit of Honda brand car Type Jazz with No. Pol B 805 following the letters RD.

\section{Unemployed wife sued her employed husband ${ }^{13}$}

This case was registered in the case No. 1825/Pdt.G/2010/PAJS which was settled on October 12, 2010, and was legally binding. The Plaintiff was Rr. Astuti Windayani binti Drs. Soehardjo R, a 53 years old housewife, who lived in Jl. Tebet Timur I Rt. 010/005 No. 18, East Tebet village in South Jakarta, with special authorization letter dated 05 October 2010. The Defendants was Drs. Djoko Santoso bin Hadi Prawiro, a 60 years Civil Servant, who lives in Jl. Tebet Timur I Rt. 010/005 No. 18, East Tebet village, South Jakarta. Both the Plaintiff and the Defendant

${ }^{12}$ Archives of the Religious Court of South Jakarta.

${ }^{13}$ Archives of the Religious Court of South Jakarta. 
are ex-husband and wife who had divorced in South Jakarta Religious Court under the divorce certificate No. 0219/AC/2010/PAJS.

During the marriage, the Plaintiffs and Defendants owned a joint property in the form of (1) land of $222 \mathrm{~m} 2$ and a permanent house of $222 \mathrm{~m} 2$ located in Tebet Timur No. 18 Tebet Jakarta with the ownership certificate No. 1329, on behalf of Rr. Windayani Astuti; (2) a land of $332 \mathrm{~m} 2$ and a two-storey house $200 \mathrm{~m} 2$ with the ownership certificate No. 06793, located at Jalan Cucak Rowo No. 2 Caturtunggal village, Depok, Sleman, Yogyakarta Province (3) A land of $406 \mathrm{~m} 2$ and building thereon with HGB No. 1018, located at the Housing Sentul City, Jalan Bunga Amanda No. 68 Village Citaringgul, Citeureup, Bogor, West Java,.

In addition, the Plaintiff and the defendant also owned a black color Honda Accord -branded car 1985 No. Pol B 6 LX, No. EZ Machine 22019675, No. SA65481854 order, No. 7075392 BPKB G on behalf of Drs. Djoko Santoso, and a unit of Ford TX No. Pol B 239 W 1997 in blur color on behalf of Rr. Astuti Windayani, as well as a unit Escudos brand car, 2002 No. Pol B 1704 KI, No. MHYESE4 engine.

In this case, there was no denial of the object property, so it could be proven that the property was owned during the marriage. Both sides decided to divide the joint property into two equal parts. However, there was a burden from the plaintiff side, who bears the cost under the name of the ownership of land and buildings, while the defendant will only help the process behind the name.

A similar settlement was taken by the Klaten Islamic Court verdict on the case No.1613/Pdt.G/2014/PA Kit. In the case, the Judges decided that the joint property was distributed equally.

\section{A lawsuit between employed husband and wife with a different final decision $^{14}$}

This case was registered in case No. 1771/Pdt.G/2008/PAJS which was settled on April 15, 2009, and was legally binding. The Plaintiff was Mukhtaron bin Nasyim, 48 years old man working in a private

${ }^{14}$ Archives of the Religious Court of South Jakarta. 
sector, who lived in Jl. M. Saidi No. 3 Rt. 009/011 South Petukangan village in Pesanggrahan Sub-district, South Jakarta. The Defendant was Rochaeni, a daughter of Yeni Kandan, a 43 years old woman working in a private company, who lived in Jl. Tridarma 4 No. 1 Rt. 005/012 Kampung Pulo village Selatan. The plaintiff and the defendants were husband and wife who married on June 27, 1997, at KUA of South Jakarta with a marriage certificate number 272/78/VI/1997. During the period of their marriage, the spouses had three children. The Plaintiff and the Defendant had divorced based on the decision of the South Jakarta Religious Court with a divorce certificate No. 529/AC/2008/PAJS. Because the divorce decision had not determined the division of joint property, the joint property lawsuit was filled separately after a divorce.

During the marriage, the Plaintiffs and the Defendants had a joint property in the form of (1) a piece of land of $50 \mathrm{~m} 2$ with the certificate No. C.1468, located at Jl. M. Saidi No. 3 Rt. 009/011 in South Petukangan village of Pesanggrahan Sub-district, South Jakarta, with a land area, the deed of sale No. 357/Pesanggrahan/1998 dated on October 15, 1998, on behalf of the Yeni Rochaeni; (2) A bataco + asbestos building on the land owned by the ex-husband (Plaintiff) located in Beiji Depok, West Java; (3) a land plot of $65 \mathrm{~m} 2$ No. C.1740 along with the 3-story building of $200 \mathrm{~m} 2$ located at Jalan M. Saidi No. 3 Rt. 009/011 in South Petukangan village of Pesanggrahan Sub-district, South Jakarta, under the deed of sale No. 357/pesanggrahan/1998 dated October 15, 1998, on behalf of Muchtarom.

In this case, The lawsuit was a pure form of joint property lawsuit, because the joint property lawsuit filed after the divorce. In its decision, the judge set the Plaintiff and the Defendant to get a half of their joint property. The verdict for the same two average was also taken by Terri Court judge in case No. 1449/Pdt.G/2014/PA.TL which was settled on September 15, 2015. This case was successfully settled.

If we draw a line between theoretical legal study (law in book) to the study of law in practical terms (law in action) on problems of joint property, it becomes clear that there is a gap in the religious courts in implementing the provisions of the Compilation of Islamic Law (KHI) 
on the division of joint property According to article $f$, subpart $f$ on $\mathrm{KHI}$, joint property is "wealth in marriage or syirkah, namely wealth derived both alone or with spouse, during a marriage without necessarily discussing who earn or own the property.

Furthermore, article 97 on KHI points out that a widow or widower has rights to get a half of joint property with an equal proportion. Similarly, the article 96 also indicates that $50 \%$ of joint property should belong to the one who is still alive. In short, according to the Law, a joint property should be divided equally regardless who are unemployed or employed.

From some of the cases above, the decisions in the case of the distribution of shared assets in the South Jakarta Religious Court did not generally come out of the KHI rules. But in practice, the provisions of KHI are not the only basis used as a reference for judges in making decisions. In other words, the provisions of KHI are not always practiced as written, but the values contained therein, namely justice. As long as the parties can be reconciled and agree to peacefully choose a solution, then their agreement is what the judge uses to resolve the dispute even though it may come out of the provisions written in the KHI.

In the view of the judges, if the marriage breaks up, either because of death or divorce, as long as there are no parties questioning the distribution of shared assets, the distribution then is by means of peace, without claiming a lawsuit. If the amount of joint assets has been determined, the division will be divided into two equals, 50\%, and 50\% regardless of who manages the assets. In accordance with the provisions of articles 96 and 97 Compilation of Islamic Law, unless the division is carried out peacefully by the parties, then $50 \%$ and $50 \%$ rules are taken into consideration.

However, very often in the distribution of shared assets among parties, the judge find difficulties to determine the number of shared assets to be shared. The most common difficulties are related to evidence that is not enough by the parties. In this case, there can be assets that are actually shared assets, but because they cannot be proven, the assets cannot be designated as joint assets.

Another problem the judges often meet is claims against savings or deposits at the bank As the judge will deal with the issue of bank secrecy, 
the parties may transfer their savings or deposits to other accounts which are difficult to track by the Court. As a result, the amount sued will not be similar to the amount found in the account. Clearly, an honesty of the parties is needed.

Thus it is clear that the rules for two (equal) as stipulated in the $\mathrm{KHI}$, are not rigidly applied by the judges for all cases of the sharing of shared assets submitted to the Religious Courts. but it is used as a reference for judges in making decisions. Therefore, in its implementation in the Religious Court, especially in the South Jakarta Religious Court the distribution of joint assets is more flexible and casuistic, depending on the judge's consideration in seeing the case.

\section{Conclusion}

In the Marriage Law No. 1 of 1974 and the Compilation of Islamic Law, it states that the joint property is only those obtained by both wife and husband during a marriage. This provision does not discuss where or from whom such property is obtained. It may include the property and income of the husband, wife's assets or income, personal property of husband and wife, provided that the wealthy are accrued throughout the marriage. The Religious Court of South Jakarta, as the other religious courts also apply, has established a rule that the settlement of joint property should be based on KHI where each of them will get a half of the joint property. However, this rule cannot always be applied in that way because sometimes the judges will get different cases. Some cases can be settled by mutual agreement, some are not. This shows that the implementation of the division of KHI and marriage law No. 1 of 1974 on the joint property depends on the cases and situations

\section{Bibliography}

Abdul, Nashori Ghofur. "Peradilan Agama di Indonesia Pasca UU No. 3 Tahun 2006, Sejarah, Kedudukan \& Kewenangan.” (Yogyakarta: UII Pers, 2007).

Agus Rudianto, Muhammad. "Pelaksanaan Pembagian Harta Bersama (Gono Gini) dalam Praktik di Pengadilan Agama Kelas I A 
Samarinda." Jurnal Beraja Niti 2, No. 9, (2013): 2.

Alaidrus, Mochammad Soleh. "Pelaksanaan Pembagian Harta Perkawinan dalam Perkawinan Poligami (Studi di Pengadilan Agama Bekasi)." Notarius 1, no. 1 (2011): 1-18.

Aminatuz Zahro, Zulfa. "Analisis Yuridis Terhadap Dasar Pertimbangan Hakim dalam Menetapkan Harta Bersama Tanpa Adanya Perceraian di Pengadilan Agama Malang: Studi Kasus Perkara Nomor: 2198/ Pdt. G/2012.” PhD diss., UIN Sunan Ampel Surabaya, 2014.

Arifin, Busthanul. Pelembagaan Hukum Islam di Indonesia: Akar Sejarah, Hambatan, dan Prospeknya (Jakarta: Gema Insani Press, 1996), h. 122.

Bisri, Cik Hasan Kompilasi Hukum Islam dan Peradilan Agama dalam Sistem Hukum Nasional, Jakarta: Logos Wacana Ilmu, 1999..

Faizal, Liky. "Harta bersama dalam Perkawinan." Ijtimaiyya: Jurnal Pengembangan Masyarakat Islam 8, no. 2 (2015): 77-102.

Harahap, M. Yahya. Kedudukan Kewenangan dan Acara Peradilan Agama (Undang-undang No. 7 Tahun 1989) Jakarta: Pustaka Kartini, 1997. Ibrahim, Ahmad. "Penerapan Asas Ius Contra Legem dalam Pembagian Harta Bersama di Pengadilan Agama Mojokerto: Studi Putusan No: 0521/Pdt. G/2013/PA.” PhD diss., Universitas Islam Negeri Maulana Malik Ibrahim, 2016.

Ismuha. Pencaharian Bersama Suami Istri Ditinjau dari Sudut Undangundang Perkawinan Tahun 1974 dan Hukum Islam, (Jakarta: Bulan Bintang, 1986), Cet. 1, h. 282.

Marcelina Waha, Felicitas. "Penyelesaian Sengketa atas Harta Perkawinan Setelah Bercerai." Lex et Societatis 1, no. 1 (2013).

Maspeke, Arifah S. dan Akhmad Khisni. "Kedudukan Harta Bersama dalam Perkawinan Menurut Fiqih dan Hukum Positif Indonesia Serta Praktik Putusan Pengadilan Agama." Jurnal Hukum Khaira Ummah 12, no. 2 (2017): 173-184.

Matrais, Sumadi. "Kemandirian Peradilan Agama dalam Perspektif UndangUndang Peradilan Agama." Jurnal Hukum Ius Quia Iustum 15, no. 1 (2008). Ahmad, R. "Peradilan Agama di Indonesia." YUDISIA: 
Jurnal Pemikiran Hukum dan Hukum Islam 6, no. 2 (2015): 311-339.

Misliranti, Yunthia. "Kedudukan dan Bagian Isteri Atas Harta Bersama Bagi Isteri yang Dicerai dari Pernikahan Sirri.” PhD diss., Program Pasca Sarjana Universitas Diponegoro, 2006.

Mokodompit, Zulfiqar. "Penerapan Hukum Positif Terhadap Harta GonoGini Dihubungkan dengan Hukum Islam.” Lex Administratum 3, no. 6 (2015).

Nikmah, Hilda Yuwafi, dan Pranoto, "Pembagian Harta Besama Akibat Perceraian dari Perkawinan Campuran Berdasarkan Undang-Undang Nomor 1 Tahun 1974 tentang Perkawinan dan Kaidah Hukum Perdata Internasional", Pirvate Law: Jurnal Pemikiran dan Penelitian Hukum, No. 6, (2014): 77.

Sutomo, Moh, Syarifah Marwiyah, dan Nur Mawaddah Warohmah. "Akar Historis Pengadilan Agama Masa Orde Baru." Yudisia: Jurnal Pemikiran Hukum dan Hukum Islam 7, no. 2 (2016): 267-284.

Wijayanti, Winda. "Kedudukan Istri dalam Pembagian Harta Bersama Akibat Putusnya Perkawinan Karena Perceraian Terkait Kerahasiaan Bank." Jurnal Konstitusi 10, no. 4 (2013): 709-730. Andayanti Lubis. "Kajian Yuridis Pertanggungjawaban Atas Harta Bawaan Isteri Terhadap Hutang Suami dengan Jaminan Harta Bersama (Studi Kasus Putusan Nomor: 295/Pdt. G/2001/PN. Mdn).” PhD diss., Program Pascasarjana Universitas Diponegoro, 2009.

\section{Others:}

Archives of the Religious Court of South Jakarta.

Interview with a clerck of court on June 28 and July 42011 at the Religious Court of South Jakarta. 